\title{
Bacillus graminis sp. nov., an endophyte isolated from a coastal dune plant
}

\author{
Fehmida Bibi, ${ }^{1}$ Eu Jin Chung, ${ }^{2}$ Che Ok Jeon ${ }^{3}$ and Young Ryun Chung ${ }^{1}$ \\ 'Division of Applied Life Science (BK 21), Plant Molecular Biology and Biotechnology Research \\ Center, Gyeongsang National University, Jinju 660-701, Republic of Korea \\ ${ }^{2} J$ Green Inc., Department of Research \& Development, Jinju 660-841, Republic of Korea \\ ${ }^{3}$ Department of Life Science, Chung-Ang University, Seoul 156-756, Republic of Korea
}

Correspondence

Young Ryun Chung

yrchung@gnu.ac.kr

\begin{abstract}
A Gram-stain-positive endophytic bacterium, designated strain $Y C 6957^{\top}$, was isolated from surface-sterilized roots of a halophyte (Elymus mollis Trin.) inhabiting coastal tidal flats of Namhae Island, located on the southern coast of Korea, and was subjected to a polyphasic taxonomic study. Cells were facultatively anaerobic, endospore-forming rods to coccoid rods, motile by a single flagellum. Strain YC6957 ${ }^{\top}$ was catalase-positive, oxidase-negative and able to grow in the presence of $0-8 \%(w / v) ~ N a C l$, with optimum growth at $4-5 \%(w / v) ~ N a C l$. Growth occurred at $15-45{ }^{\circ} \mathrm{C}$ (optimal growth at $30-35^{\circ} \mathrm{C}$ ) and $\mathrm{pH} 6.0-8.5$ (optimal growth at $\mathrm{pH}$ 7.0-8.0). The predominant isoprenoid quinone was menaquinone 7 (MK-7). The major cellular fatty acids were $\mathrm{C}_{16: 0}(11.3 \%)$, iso- $\mathrm{C}_{15: 0}(19.2 \%)$ and anteiso- $\mathrm{C}_{15: 0}(36.4 \%)$. The cell-wall peptidoglycan contained meso-diaminopimelic acid. The major polar lipids were diphosphatidylglycerol, phosphatidylglycerol and phosphatidylethanolamine. The DNA G+C content was $41.6 \mathrm{~mol} \%$. Phylogenetic analysis based on the 16S rRNA gene sequence revealed that the isolate belonged to the genus Bacillus. Strain YC6957 $7^{\top}$ exhibited high 16S rRNA gene sequence similarity to its closest neighbours, Bacillus ruris LMG $22866^{\top}(96.14 \%)$, Bacillus lentus NCIMB $8773^{\top}$ (95.97\%) and Bacillus galactosidilyticus LMG $17892^{\top}$ (95.91\%), and less than $95.84 \%$ similarity to all other type strains in the genus Bacillus. On the basis of the phylogenetic, physiological and biochemical data, it is suggested that strain $Y C 6957^{\top}$ represents a novel species of the genus Bacillus, for which the name Bacillus graminis sp. nov. is proposed. The type strain is ${\text { YC } 6957^{\top}}^{\top}\left(=\right.$ KACC $13779^{\top}=$ DSM $\left.22162^{\top}\right)$.
\end{abstract}

Species of the genus Bacillus have been isolated from a wide variety of environments, and their ubiquitous distribution in nature is due to the resistance of their endospores to stressful environmental conditions. Members of the genus Bacillus are also common residents of internal tissues of terrestrial and aquatic plants, where these micro-organisms play an important role in plant protection and growth promotion and facilitate plant growth under biotic and abiotic stress conditions (Ji et al., 2008; Sgroy et al., 2009). Although Bacillus species have been isolated from a wide range of habitats, to the best of our knowledge, only one Bacillus strain belonging to a species with a validly published name, Bacillus endophyticus (Reva et al., 2002), has been isolated from inner tissues of a plant root. In the course of a study of the endophytic bacterial diversity of coastal sand-dune halophytes, several endophytes related to

The GenBank/EMBL/DDBJ accession number for the $16 \mathrm{~S}$ rRNA gene sequence of strain YC6957 ${ }^{\top}$ is GU322908.

Two supplementary figures are available with the online version of this paper. the genus Bacillus were isolated from different halophytes, and a novel strain, YC6957 $7^{\mathrm{T}}$, belonging to the genus Bacillus was isolated from the roots of a dune grass.

Strain YC6957 ${ }^{\mathrm{T}}$ was isolated from the roots of a coastal sand-dune plant, Elymus mollis Trin., growing on coastal tidal flats of Namhae Island $\left(34^{\circ} 50^{\prime} 15.62^{\prime \prime} \mathrm{N} 127^{\circ} 53^{\prime}\right.$ $32.72^{\prime \prime} \mathrm{E}$ ), located midway along the south coast of Korea. Isolation was carried out as described previously (Chung et al., 2008). Root pieces were washed several times with running tap water and surface sterilized by stepwise washing in $70 \%$ ethanol for $5 \mathrm{~min}, 1.0 \% \mathrm{NaOCl}$ for $10 \mathrm{~min}$ and $70 \%$ ethanol for about $10 \mathrm{~s}$ and finally washed several times with sterile distilled water. To confirm the success of the disinfection process, washed root segments were placed on R2A agar (Difco) for examination of bacterial growth after incubation at $28{ }^{\circ} \mathrm{C}$ for $5-6$ days. After confirmation of the surface sterility of root segments, $1.0 \mathrm{~g}$ dried plant root was ground with a sterile mortar and pestle in $9.0 \mathrm{ml}$ autoclaved filtered seawater (AFS). Serial dilutions were made using AFS and $200 \mu \mathrm{l}$ aliquots of the $10^{-3}$ to $10^{-5}$ dilutions were spread on one-tenth strength 
R2A (1/10 R2A) plates and incubated at $25{ }^{\circ} \mathrm{C}$ for $1-2$ weeks. The purified strain was maintained on marine agar 2216 (MA; Difco) or half-strength R2A (1/2 R2A) agar.

Thirty-two strains isolated from roots were identified on the basis of $16 \mathrm{~S}$ rRNA gene sequence similarity and the similarities to related genera were in the range $96.1-100 \%$. One novel strain designated $\mathrm{YC} 6957^{\mathrm{T}}$ had the closest similarity $(96.14 \%)$ to Bacillus ruris LMG $17892^{\mathrm{T}}$, while relatively low sequence similarities (95.84-93.09\%) were found to the type strains of other species of the genus Bacillus with validly published names.

Cell morphology was observed using transmission electron microscopy (Hitachi model H-600) with cells grown for 1 day at $30{ }^{\circ} \mathrm{C}$ in R2A broth (Difco). The Gram reaction was determined by using the bioMerieux Gram stain kit according to the manufacturer's instructions. Motility was checked using the hanging-drop method (Schaal, 1986). Cells were rods to coccoid rods with a single polar flagellum (Fig. 1). The $\mathrm{pH}$ range for growth was tested using 1/2 R2A broth, adjusted to different $\mathrm{pH}$ values by using the appropriate biological buffers, as described by $\mathrm{Xu}$ et al. (2005). The temperature for growth was determined by incubating strain $\mathrm{YC} 6957^{\mathrm{T}}$ on $1 / 2 \mathrm{R} 2 \mathrm{~A}$ agar at 4 to $50{ }^{\circ} \mathrm{C}$ and the optimum temperature for growth was determined in $1 / 2$ R2A broth by turbidity at $600 \mathrm{~nm}$ using a spectroscopic method (Optizen 2120UV; Mechasis). Requirement for and tolerance of $\mathrm{NaCl}$ were determined in 1/2 R2A broth supplemented with $1-10 \%(\mathrm{w} / \mathrm{v}) \mathrm{NaCl}$. Catalase and oxidase tests were performed by the procedures outlined by Cappuccino \& Sherman (2002). Nitrate reduction was determined according to the method of Lányí (1987). Modified Schaeffer's medium (MSM) was used to induce

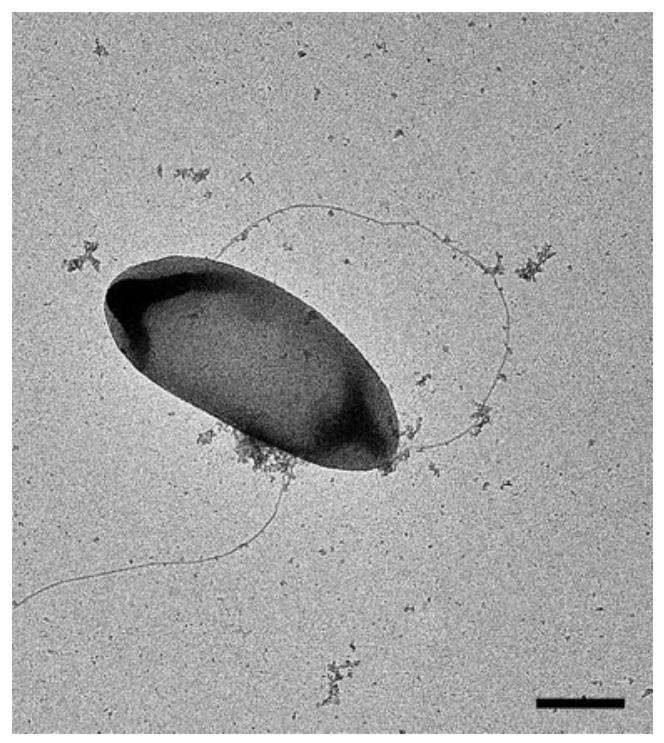

Fig. 1. Transmission electron micrograph of a cell of Bacillus graminis sp. nov. $\mathrm{YC} 6557^{\top}$, grown in $1 / 2 \mathrm{R} 2 \mathrm{~A}$ broth for 1 day at $30{ }^{\circ} \mathrm{C}$. Bar, $0.5 \mu \mathrm{m}$. sporulation, as described by Kempf et al. (2005). The lecithinase test was performed as described previously (Gordon et al., 1973). Anaerobic growth was determined at $28{ }^{\circ} \mathrm{C}$ after 2 weeks of incubation in the GasPak EZ Anaerobe Pouch System (BD) on 1/2 R2A agar according to the manufacturer's instructions. Physiological properties of strain $\mathrm{YC} 6957^{\mathrm{T}}$ and related type strains B. ruris KACC $12113^{\mathrm{T}}$, B. lentus KACC $10930^{\mathrm{T}}$ and B. galactosidilyticus DSM $15595^{\mathrm{T}}$ were determined using the following methods: hydrolysis of casein, gelatin, tyrosine, starch, aesculin, urea (Lányí, 1987; Smibert \& Krieg, 1994), cellulose (Hendricks et al., 1995) and chitin (Singh et al., 1999) and $\beta$-1, 3glucanase (Hong \& Meng, 2003). API 20E tests (bioMérieux) were used to determine nitrate reduction, aesculin hydrolysis, $\beta$-galactosidase production, fermentation of glucose, the ONPG test ( $\beta$-galactosidase), urease, gelatinase and indole production. Acid-production profiles from carbohydrates were obtained with the API $50 \mathrm{CH}$ system (bioMérieux) after growth in $50 \mathrm{CHB}$ medium according to the manufacturer's instructions. Phenotypic, physiological and biochemical characteristics of strain $\mathrm{YC} 6957^{\mathrm{T}}$ are listed in the species description and are given in Table 1.

For measurement of the $\mathrm{G}+\mathrm{C}$ content of the chromosomal DNA, genomic DNA was extracted and purified as described by Ausubel et al. (1995). Purified genomic DNA was then digested enzymically into nucleotides and the $\mathrm{G}+\mathrm{C}$ content was determined as described by Mesbah et al. (1989) using reversed-phase HPLC. Menaquinones were isolated using the methods of Minnikin et al. (1984) and separated by HPLC (Kroppenstedt, 1982). The G+C content of the genomic DNA of strain $\mathrm{YC} 6957^{\mathrm{T}}$ was $41.6 \mathrm{~mol} \%$. Strain YC6957 ${ }^{\mathrm{T}}$ contained MK-7 $(97.4 \%)$ as the predominant menaquinone, with MK-8 (2.6\%) present in minor amounts. The $16 \mathrm{~S}$ rRNA gene was amplified from extracted DNA by using primers $27 \mathrm{~F}$ and $1492 \mathrm{R}$ (Lane, 1991). The purified PCR product was sequenced by GenoTech Co. Ltd (Daejeon, Korea). To ascertain the phylogenetic position of the novel strain, the 16S rRNA gene sequence $(1.4 \mathrm{~kb})$ of strain $\mathrm{YC} 6957^{\mathrm{T}}$ was compared with sequences obtained from NCBI and the EzTaxon server (http://www.eztaxon.org/; Chun et al., 2007). Multiple alignments of sequences were performed by using CLUSTAL_X (version 1.83) (Thompson et al., 1997). Gaps were edited in the BioEdit program (Hall, 1999). Evolutionary distances were calculated using Kimura's twoparameter model (Kimura, 1983). Phylogenetic trees were reconstructed by using the neighbour-joining method (Saitou \& Nei, 1987) in the MEGA4 program (Tamura et al., 2007) with bootstrap values based on 1000 replications (Felsenstein, 1985). A phylogenetic tree based on the maximum-likelihood algorithm was also reconstructed using the PHYLIP program, version 3.6 (Felsenstein, 2002). Comparative analysis of $16 \mathrm{~S}$ rRNA gene sequences revealed that strain $\mathrm{YC} 657^{\mathrm{T}}$ belonged to the genus Bacillus, exhibiting the highest sequence similarity to $B$. ruris LMG $22866^{\mathrm{T}}(96.14 \%)$, B. lentus NCIMB $8773^{\mathrm{T}}(95.97 \%)$ and $B$. galactosidilyticus $\mathrm{LMG} 17892^{\mathrm{T}}$ (95.91\%), while relatively 
Table 1. Characteristics that differentiate Bacillus graminis sp. nov. YC6957 ${ }^{\top}$ from type strains of phylogenetically related Bacillus species

Strain: 1, B. graminis YC6957 $; 2$, B. ruris KACC $12113^{\mathrm{T}} ; 3$, B. galactosidilyticus DSM $15595^{\mathrm{T}}$; 4, B. lentus KACC $10930^{\mathrm{T}}$. Data were obtained this study unless indicated. +, Positive; -, negative; $\mathrm{W}$, weak positive reaction.

\begin{tabular}{|c|c|c|c|c|}
\hline Characteristic & 1 & 2 & 3 & 4 \\
\hline Isolation source & Plant & $\begin{array}{l}\text { Dairy farm } \\
\text { feed }^{a_{\star}}\end{array}$ & Raw milk ${ }^{b}$ & Soil $^{c}$ \\
\hline Swollen sporangia & + & $+^{a}$ & $+{ }^{b}$ & $-^{c}$ \\
\hline $\mathrm{pH}$ for growth & $6.0-8.5$ & $6.5-11.0$ & $5.5-10.5$ & $6.0-9.5$ \\
\hline $\begin{array}{l}\text { Temperature for } \\
\text { growth }\left({ }^{\circ} \mathrm{C}\right)\end{array}$ & $15-45$ & $20-40$ & $20-40$ & $15-35$ \\
\hline Oxidase & - & - & - & + \\
\hline Anaerobic growth & + & + & + & - \\
\hline Nitrate reduction & + & - & + & + \\
\hline Citrate utilization & - & - & - & $\mathrm{w}$ \\
\hline Urease production & - & - & - & + \\
\hline \multicolumn{5}{|l|}{ Hydrolysis of: } \\
\hline Casein & $\mathrm{W}$ & - & $\mathrm{W}$ & - \\
\hline Cellulose & $\mathrm{w}$ & - & + & + \\
\hline \multicolumn{5}{|l|}{ Acid production from: } \\
\hline L-Arabinose & $\mathrm{W}$ & + & $\mathrm{W}$ & - \\
\hline D-Xylose & $\mathrm{w}$ & + & - & $\mathrm{w}$ \\
\hline L-Xylose & - & - & - & $\mathrm{w}$ \\
\hline D-Galactose & - & - & - & $\mathrm{w}$ \\
\hline D-Mannose & + & $\mathrm{W}$ & $\mathrm{W}$ & - \\
\hline D-Rhamnose & - & - & - & $\mathrm{w}$ \\
\hline D-Mannitol & $\mathrm{w}$ & - & - & $\mathrm{w}$ \\
\hline $\mathrm{N}$-Acetylglucosamine & - & + & + & - \\
\hline Amygdalin & $\mathrm{w}$ & - & + & - \\
\hline Lactose & - & + & $\mathrm{w}$ & $\mathrm{w}$ \\
\hline Melibiose & - & + & + & $\mathrm{w}$ \\
\hline Sucrose & - & + & $\mathrm{w}$ & $\mathrm{w}$ \\
\hline Melezitose & - & + & $\mathrm{W}$ & $\mathrm{w}$ \\
\hline Raffinose & - & - & - & + \\
\hline Gentiobiose & - & - & - & W \\
\hline $\begin{array}{l}\text { DNA G }+ \text { C content } \\
(\mathrm{mol} \%)\end{array}$ & 41.6 & $39.2^{a}$ & $37.7^{b}$ & $36.3^{c}$ \\
\hline
\end{tabular}

${ }^{\star}$ Data taken from: a, Heyndrickx et al. (2005); b. Heyndrickx et al. (2004); c, Spanka \& Fritze (1993).

low sequence similarities (95.84-93.09\%) were observed to other members of the genus Bacillus. The phylogenetic tree reconstructed using the neighbour-joining algorithm further confirmed that strain YC6957 ${ }^{\mathrm{T}}$ was phylogenetically related closely to species of the genus Bacillus and formed a robust lineage with the type strains of $B$. galactosidilyticus and B. ruris (Supplementary Fig. S1a, available in IJSEM Online). The topology was similar to that of the phylogenetic tree constructed by using the maximum-likelihood method (Supplementary Fig. S1b).

Analysis of cellular fatty acid methyl esters was performed for strain $\mathrm{YC} 657^{\mathrm{T}}$ and the closely related strains B. ruris
KACC $12113^{\mathrm{T}}$, B. lentus KACC $10930^{\mathrm{T}}$ and B. galactosidilyticus DSM $15595^{\mathrm{T}}$ from cells grown on TSBA (Difco) for $36 \mathrm{~h}$ at $30^{\circ} \mathrm{C}$. Cellular fatty acids were saponified, methylated and extracted according to Sasser (1990). The fatty acids were separated by GC (Hewlett Packard 6890) and identified using the Microbial Identification software package (Microbial ID, Inc.). Whole-cell fatty acid analysis of strain $\mathrm{YC} 657^{\mathrm{T}}$ revealed the dominance of $\mathrm{C}_{16: 0}$ $(11.3 \%)$, iso- $\mathrm{C}_{15: 0}(19.2 \%)$ and anteiso- $\mathrm{C}_{15: 0}(36.4 \%)$, which comprised approximately $70 \%$ of the cellular fatty acids extracted. Branched fatty acids of the 14- to 17carbon iso and anteiso series are typically the major fatty acids found in Bacillus cell membranes (Kämpfer, 1994). However, strain $\mathrm{YC} 657^{\mathrm{T}}$ and the type strains B. ruris KACC $12113^{\mathrm{T}}$, B. lentus KACC $10930^{\mathrm{T}}$ and B. galactosidilyticus DSM $15595^{\mathrm{T}}$ could be distinguished clearly from each other based on relative fatty acid concentrations (Table 2).

Amino acids of whole-cell hydrolysates of strain YC $6957^{\mathrm{T}}$ were extracted and analysed according to the method of Staneck \& Roberts (1974). Polar lipids were extracted by a modified method of Minnikin et al. (1984) and separated by TLC on Merck Kieselgel 60-HPTLC. Aminolipids were detected by spraying the plate with a $0.2 \%(\mathrm{w} / \mathrm{v})$ solution of ninhydrin in butanol saturated with water followed by heating at $105{ }^{\circ} \mathrm{C}$ for $10 \mathrm{~min}$ (Ross et al., 1985). Phospholipids were detected by spraying the plate with Zinzadze reagent (Dittmer \& Lester, 1964). Glycolipids were detected with $0.5 \%$ 1-naphthol in methanol/water

Table 2. Fatty acid methyl ester composition of $B$. graminis sp. nov. YC6957 ${ }^{\top}$ and type strains of related species

Strain: 1, B. graminis YC6957 ${ }^{\mathrm{T}}$; 2, B. ruris KACC $12113^{\mathrm{T}}$; 3, B. galactosidilyticus DSM $15595^{\mathrm{T}}$; 4, B. lentus KACC $10930^{\mathrm{T}}$. Data were obtained in this study and are expressed as percentages of total fatty acids. tr, Less than $1.0 \%$ of total fatty acids; -, not detected.

\begin{tabular}{|lcccc|}
\hline Fatty acid & $\mathbf{1}$ & $\mathbf{2}$ & $\mathbf{3}$ & $\mathbf{4}$ \\
\hline Straight-chain saturated & & & & \\
$\mathrm{C}_{12: 0}$ & 2.5 & $\operatorname{tr}$ & $\operatorname{tr}$ & - \\
$\mathrm{C}_{14: 0}$ & 2.7 & 4.7 & 5.6 & 5.7 \\
$\mathrm{C}_{15: 0}$ & 4.7 & 9.2 & 8.1 & - \\
$\mathrm{C}_{16: 0}$ & 11.3 & 21.4 & 17.2 & 16.8 \\
$\mathrm{C}_{17: 0}$ & - & $\operatorname{tr}$ & - & - \\
$\mathrm{C}_{18: 0}$ & $\operatorname{tr}$ & $\operatorname{tr}$ & - & 1.1 \\
Branched saturated $_{\text {iso- }} \mathrm{C}_{14: 0}$ & & & & \\
iso- $\mathrm{C}_{15: 0}$ & 6.2 & 2.6 & 5.7 & 6.0 \\
iso- $\mathrm{C}_{16: 0}$ & 19.2 & 13.3 & 14.9 & 11.6 \\
iso- $\mathrm{C}_{17: 0}$ & 7.5 & 4.9 & 4.8 & 5.5 \\
anteiso- $\mathrm{C}_{15: 0}$ & 1.8 & 3.0 & 1.4 & 1.3 \\
anteiso- $\mathrm{C}_{17: 0}$ & 36.4 & 34.1 & 34.2 & 41.5 \\
anteiso- $\mathrm{C}_{19: 0}$ & 3.8 & 4.7 & 3.7 & 6.8 \\
Mono-unsaturated & 1.2 & $\operatorname{tr}$ & - & - \\
$\mathrm{C}_{16: 1} \omega 11 c$ & & & & \\
\hline
\end{tabular}


$(1: 1, \mathrm{v} / \mathrm{v})$ and then with sulfuric acid/ethanol $(1: 1, \mathrm{v} / \mathrm{v})$, followed by heating at $120{ }^{\circ} \mathrm{C}$ for $5-10 \mathrm{~min}$ (Xin et al., 2001). Total lipids were detected by spraying with phosphomolybdic acid solution (Sigma-Aldrich) followed by heating at $150{ }^{\circ} \mathrm{C}$. Analysis of cell-wall hydrolysates of strain YC $6957^{\mathrm{T}}$ revealed the presence of meso-diaminopimelic acid as the diagnostic cell-wall diamino acid. Diphosphatidylglycerol, phosphatidylethanolamine and phosphatidylglycerol were predominant in the polar lipid profile; we also detected an unknown phospholipid, an unknown glycolipid and two unknown polar lipids (Supplementary Fig. S2). A similar polar lipid profile, containing the same predominant compounds as well as the unknown phospholipid and the unknown polar lipid, was detected in B. galactosidilyticus DSM $15595^{\mathrm{T}}$, but the presence of an unknown aminophospholipid and an unknown phospholipid clearly distinguished strain $\mathrm{YC} 657^{\mathrm{T}}$ from the related strain $B$. galactosidilyticus DSM $15595^{\mathrm{T}}$. The major fatty acid profile, respiratory lipoquinone, major polar lipids and peptidoglycan type of the cell wall of strain YC6957 ${ }^{\mathrm{T}}$ were typical of those of members of the genus Bacillus (Priest et al., 1988; Wieser et al., 2005; Lim et al., 2006a, b, c).

The results of the phylogenetic analysis and morphological and chemotaxonomic investigations supported the affiliation of strain $\mathrm{YC} 6957^{\mathrm{T}}$ to the genus Bacillus. The characteristics that differentiate strain $\mathrm{YC} 657^{\mathrm{T}}$ from related Bacillus species are summarized in Table 1 . Differences in biochemical characteristics, $16 \mathrm{~S}$ rRNA gene sequences, isolation source, DNA G $+\mathrm{C}$ content, hydrolytic enzyme production and fatty acid composition can be used to distinguish this strain from phylogenetically related taxa (Tables 1 and 2). Therefore, on the basis of these data, according to the minimal standards for describing new taxa of aerobic, endospore-forming bacteria (Logan et al., 2009), we propose that strain YC6957 ${ }^{\mathrm{T}}$ represents a novel species of the genus Bacillus, for which the name Bacillus graminis sp. nov. is proposed.

\section{Description of Bacillus graminis sp. nov.}

Bacillus graminis (gra'mi.nis. L. gen. neut. n. graminis of grass).

Cells are Gram-stain-positive, facultatively anaerobic rods to coccoid rods, $0.7-1.0 \times 1.2-2.2 \mu \mathrm{m}$. They bear an ellipsoidal endospore that lies in a subterminal position. Motile by a single polar flagellum. After 2 days on 1/2 R2A, colonies are semi-transparent and whitish in colour with opaque centres. Cells usually occur singly or in pairs; tetrad-like cells are common. Cells are catalase-positive and oxidase-negative. Grows at $15-45{ }^{\circ} \mathrm{C}$ (optimum $30-35{ }^{\circ} \mathrm{C}$ ), but not at 10 or $50{ }^{\circ} \mathrm{C}$. Grows at $\mathrm{pH} 6.0-8.5$ but not at $\mathrm{pH} 5.5$ or 9.0. Growth is observed in R2A broth containing $8 \%(\mathrm{w} / \mathrm{v}) \mathrm{NaCl}$ but not $9.0 \%(\mathrm{w} / \mathrm{v}) \mathrm{NaCl}$. Nitrate is reduced to nitrite. Hydrolysis of aesculin is positive; weakly positive for hydrolysis of casein and cellulose. Does not hydrolyse gelatin, chitin or urea. Citrate is not utilized. Indole production and egg-yolk reaction are negative. In API 20E tests, nitrate is reduced to nitrite; negative for
ONPG reaction, activities of arginine dihydrolase, lysine decarboxylase, ornithine decarboxylase and urease, citrate utilization, hydrogen sulfide production, the VogesProskauer reaction, indole production and gelatin hydrolysis. Positive for acid production from L-arabinose, D-xylose, D-mannose, D-mannitol and amygdalin, but negative for acid production from erythritol, $\mathrm{D}$-arabinose, D-ribose, L-xylose, D-adonitol, methyl $\beta$-D-xylopyranoside, D-galactose, D-glucose, D-fructose, L-sorbose, L-rhamnose, dulcitol, inositol, D-sorbitol, methyl $\alpha$-D-glucopyranoside, methyl $\alpha$-D-mannopyranoside, $N$-acetylglucosamine, arbutin, salicin, cellobiose, maltose, inulin, melezitose, gentiobiose, raffinose, D-lyxose, D-fucose, D- and L-arabitol, potassium gluconate, potassium 2-ketogluconate and potassium 5-ketogluconate. Positive for utilization of D- and L-arabinose, D-ribose, D-xylose, D-galactose, D-glucose, D-fructose, sucrose, D-mannose, D-mannitol and amygdalin. The major respiratory menaquinone is MK-7. The diagnostic diamino acid of the cell-wall peptidoglycan is mesodiaminopimelic acid. Major fatty acid components $(>10 \%$ of the total) are $\mathrm{C}_{16: 0}$, iso- $\mathrm{C}_{15: 0}$ and anteiso- $\mathrm{C}_{15: 0}$. Major polar lipids are diphosphatidylglycerol, phosphatidylethanolamine and phosphatidylglycerol; an unknown phospholipid, an unknown glycolipid and two unknown lipids are minor components. The $\mathrm{G}+\mathrm{C}$ content of the genomic DNA of the type strain is $41.6 \mathrm{~mol} \%$.

The type strain, YC6957 $7^{\mathrm{T}}\left(=\right.$ KACC $13779^{\mathrm{T}}=$ DSM $\left.22162^{\mathrm{T}}\right)$, was isolated from internal tissue of roots of Elymus mollis Trin. growing on the coast of Namhae Island, Korea.

\section{Acknowledgements}

This work was supported by a grant from the Brain Korea (BK) 21 project in 2008-2009, Ministry of Education, Science and Technology, Korea. E. J.C. was partially supported by a project for training industrial researchers of the Ministry of Knowledge Economy, Korea.

\section{References}

Ausubel, F. W., Brent, R., Kingston, R. E., Moore, D. D., Seidman, J. G., Smith, J. A. \& Struhl, K. (1995). Current Protocols in Molecular Biology. New York: Wiley.

Cappuccino, J. G. \& Sherman, N. (2002). Microbiology: a Laboratory Manual, 6th edn. Menlo Park, CA: Benjamin/Cummings.

Chun, J., Lee, J.-H., Jung, Y., Kim, M., Kim, S., Kim, B. K. \& Lim, Y. W. (2007). EzTaxon: a web-based tool for the identification of prokaryotes based on $16 \mathrm{~S}$ ribosomal RNA gene sequences. Int J Syst Evol Microbiol 57, 2259-2261.

Chung, B. S., Aslam, Z., Kim, S. W., Kim, G. G., Kang, H. S., Ahn, J. W. \& Chung, Y. R. (2008). A bacterial endophyte, Pseudomonas brassicacearum YC5480 isolated from the root of Artemisia sp. producing antifungal and phytotoxic compounds. Plant Pathol J 24, 461-468.

Dittmer, J. C. \& Lester, R. L. (1964). A simple, specific spray for the detection of phospholipids on thin-layer chromatograms. J Lipid Res 15, 126-127.

Felsenstein, J. (1985). Confidence limits on phylogenies: an approach using the bootstrap. Evolution 39, 783-791. 
Felsenstein, J. (2002). PHYLIP (phylogeny inference package), version 3.6a. Distributed by the author. Department of Genome Sciences, University of Washington, Seattle, USA.

Gordon, R. E., Haynes, W. C. \& Pang, C. H.-N. (1973). The Genus Bacillus. Agriculture Handbook no. 427. Washington, DC: United States Department of Agriculture.

Hall, T. A. (1999). BioEdit: a user-friendly biological sequence alignment editor and analysis program for Windows 95/98/NT. Nucleic Acids Symp Ser 41, 95-98.

Hendricks, C. W., Doyle, J. D. \& Hugley, B. (1995). A new solid medium for enumerating cellulose-utilizing bacteria in soil. Appl Environ Microbiol 61, 2016-2019.

Heyndrickx, M., Logan, N. A., Lebbe, L., Rodríguez-Díaz, M., Forsyth, G., Goris, J., Scheldeman, P. \& De Vos, P. (2004). Bacillus galactosidilyticus sp. nov., an alkali-tolerant beta-galactosidase producer. Int J Syst Evol Microbiol 54, 617-621.

Heyndrickx, M., Scheldeman, P., Forsyth, G., Lebbe, L., Rodriguez-Díaz, M., Logan, N. A. \& De Vos, P. (2005). Bacillus ruris sp. nov., from dairy farms. Int J Syst Evol Microbiol 55, 2551-2554.

Hong, T. Y. \& Meng, M. (2003). Biochemical characterization and antifungal activity of an endo-1,3-beta-glucanase of Paenibacillus sp. isolated from garden soil. Appl Microbiol Biotechnol 61, 472-478.

Ji, X., Lu, G., Gai, Y., Zheng, C. \& Mu, Z. (2008). Biological control against bacterial wilt and colonization of mulberry by an endophytic Bacillus subtilis strain. FEMS Microbiol Ecol 65, 565-573.

Kämpfer, P. (1994). Limits and possibilities of total fatty acid analysis for classification and identification of Bacillus species. Syst Appl Microbiol 17, 86-98.

Kempf, M. J., Chen, F., Kern, R. \& Venkateswaran, K. (2005). Recurrent isolation of hydrogen peroxide-resistant spores of Bacillus pumilus from a spacecraft assembly facility. Astrobiology 5, 391-405.

Kimura, M. (1983). The Neutral Theory of Molecular Evolution. Cambridge: Cambridge University Press.

Kroppenstedt, R. M. (1982). Separation of bacterial menaquinones by HPLC using reverse phase (RP18) and a silver loaded ion exchanger as stationary phases. J Liq Chromatogr 5, 2359-2367.

Lane, D. J. (1991). 16S/23S rRNA sequencing. In Nucleic Acid Techniques in Bacterial Systematics, pp. 115-175. Edited by E. Stackebrandt \& M. Goodfellow. Chichester: Wiley.

Lányí, B. (1987). Classical and rapid identification methods for medically important bacteria. Methods Microbiol 19, 1-67.

Lim, J.-M., Jeon, C. O., Lee, J. C., Ju, Y. J., Park, D. J. \& Kim, C.-J. (2006a). Bacillus koreensis sp. nov., a spore-forming bacterium, isolated from the rhizosphere of willow roots in Korea. Int J Syst Evol Microbiol 56, 59-63.

Lim, J.-M., Jeon, C. O., Lee, S.-M., Lee, J. C., Xu, L. H., Jiang, C. L. \& Kim, C. J. (2006b). Bacillus salarius sp. nov., a halophilic, sporeforming bacterium isolated from a salt lake in China. Int J Syst Evol Microbiol 56, 373-377.

Lim, J.-M., Jeon, C. O. \& Kim, C.-J. (2006c). Bacillus taeanensis sp. nov., a halophilic Gram-positive bacterium from a solar saltern in Korea. Int J Syst Evol Microbiol 56, 2903-2908.

Logan, N. A., Berge, O., Bishop, A. H., Busse, H. J., De Vos, P., Fritze, D., Heyndrickx, M., Kämpfer, P., Rabinovitch, L. \& other authors (2009). Proposed minimal standards for describing new taxa of aerobic, endospore-forming bacteria. Int J Syst Evol Microbiol 59, 2114-2121.

Mesbah, M., Premachandran, U. \& Whitman, W. B. (1989). Precise measurement of the $\mathrm{G}+\mathrm{C}$ content of deoxyribonucleic acid by highperformance liquid chromatography. Int J Syst Bacteriol 39, 159-167.
Minnikin, D. E., O’Donnell, A. G., Goodfellow, M., Alderson, G., Athalye, M., Schaal, A. \& Parlett, J. H. (1984). An integrated procedure for the extraction of bacterial isoprenoid quinones and polar lipids. J Microbiol Methods 2, 233-241.

Priest, F. G., Goodfellow, M. \& Todd, C. (1988). A numerical classification of the genus Bacillus. J Gen Microbiol 134, 18471882.

Reva, O. N., Smirnov, V. V., Pettersson, B. \& Priest, F. G. (2002). Bacillus endophyticus sp. nov., isolated from the inner tissues of cotton plants (Gossypium sp.). Int J Syst Evol Microbiol 52, 101-107.

Ross, H. N. M., Grant, W. D. \& Harris, J. E. (1985). Lipids in archaebacterial taxonomy. In Chemical Methods in Bacterial Systematics, pp. 289-300. Edited by M. Goodfellow \& D. E. Minnikin. London: Academic Press.

Saitou, N. \& Nei, M. (1987). The neighbor-joining method: a new method for reconstructing phylogenetic trees. Mol Biol Evol 4, 406425.

Sasser, M. (1990). Identification of bacteria by gas chromatography of cellular fatty acids. MIDI Technical Note 101. Newark, DE: MIDI, Inc.

Schaal, K. P. (1986). Genus Actinomyces Harz 1877, 133 ${ }^{\mathrm{AL}}$. In Bergey's Manual of Systematic Bacteriology, vol. 2, pp. 1383-1418. Edited by P. H. A. Sneath, N. S. Mair, M. E. Sharpe \& J. G. Holt. Baltimore: Williams \& Wilkins.

Sgroy, V., Cassán, F., Masciarelli, O., Del Papa, M. F., Lagares, A. \& Luna, V. (2009). Isolation and characterization of endophytic plant growth-promoting (PGPB) or stress homeostasis-regulating (PSHB) bacteria associated to the halophyte Prosopis strombulifera. Appl Microbiol Biotechnol 85, 371-381.

Singh, P. P., Shin, Y. C., Park, C. S. \& Chung, Y. R. (1999). Biological controls of Fusarium wilt of cucumber by chitinolytic bacteria. Phytopathology 89, 92-99.

Smibert, R. M. \& Krieg, N. R. (1994). Phenotypic characterization. In Methods for General and Molecular Bacteriology, pp. 607-654. Edited by P. Gerhardt, R. G. E. Murray, W. A. Wood \& N. R. Krieg. Washington, DC: American Society for Microbiology.

Spanka, R. \& Fritze, D. (1993). Bacillus cohnii sp. nov., a new, obligately alkaliphilic, oval-spore-forming Bacillus species with ornithine and aspartic acid instead of diaminopimelic acid in the cell wall. Int J Syst Bacteriol 43, 150-156.

Staneck, J. L. \& Roberts, G. D. (1974). Simplified approach to identification of aerobic actinomycetes by thin-layer chromatography. Appl Microbiol 28, 226-231.

Tamura, K., Dudley, J., Nei, M. \& Kumar, S. (2007). MEGA4: molecular evolutionary genetics analysis (MEGA) software version 4.0. Mol Biol Evol 24, 1596-1599.

Thompson, J. D., Gibson, T. J., Plewniak, F., Jeanmougin, F. \& Higgins, D. G. (1997). The CLUSTAL_X windows interface: flexible strategies for multiple sequence alignment aided by quality analysis tools. Nucleic Acids Res 25, 4876-4882.

Wieser, M., Worliczek, H., Kämpfer, P. \& Busse, H.-J. (2005). Bacillus herbersteinensis sp. nov. Int J Syst Evol Microbiol 55, 2119-2123.

Xin, H., Itoh, T., Zhou, P., Suzuki, K. \& Nakase, T. (2001). Natronobacterium nitratireducens sp. nov., a haloalkaliphilic archaeon isolated from a soda lake in China. Int J Syst Evol Microbiol 51, 18251829.

Xu, P., Li, W. J., Tang, S. K., Zhang, Y. Q., Chen, G. Z., Chen, H. H., Xu, L. H. \& Jiang, C. L. (2005). Naxibacter alkalitolerans gen. nov., sp. nov., a novel member of the family 'Oxalobacteraceae' isolated from China. Int J Syst Evol Microbiol 55, 1149-1153. 